\title{
Optimization of Refining Strategy to Fractionate Various Iraqi Crude Oils
} into Lighter Fractions

$$
\text { توصيف وتصنيف واختيار أفضل استراتيجية تكرير للنفوط الخام العراقية }
$$

Dr. Zaidoon M. Shakor ${ }^{*}$, Salah M. Ali ${ }^{* *}$, Harith A. Mohammed ${ }^{* *}$, Talal F. Hassan ${ }^{* *}$

${ }^{*}$ Chemical Engineering Department $\backslash$ University of Technology Iraq.

${ }^{* *}$ Oil Research and Development Center\Oil Ministry Iraq.

$$
\begin{aligned}
& \text { الخغاة } \\
& \text { الهدف الرئيسي لهذه الدراسة هي وصف وتقييم النفوط الخام العر اقية والتنبؤ باستراتيجية التكرير المثلى لتكرير مختلف النفوط } \\
& \text { الخام إلى منتجات أخف اعتمادا على الطلب الثهري في السوق العر اقية على طول السنة. } \\
& \text { تم حساب الاستهلاك الثهري من الكازولين والكيروسن وزيت الغاز على مدى سنة واحدة و استخدامت طريقة الاختيار }
\end{aligned}
$$

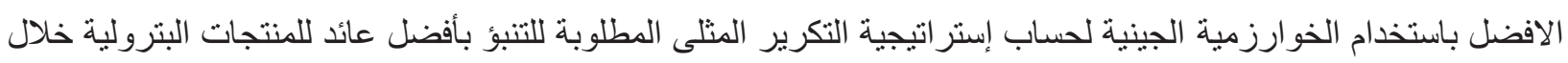

$$
\begin{aligned}
& \text { عام و احد. } \\
& \text { اظهرت النتائج انه بتقطير مزيج من ثلاثة نفوط خام يمكن الحصول على المنتجات الخفيفة المطلوب باستخدام كمية من النفط }
\end{aligned}
$$

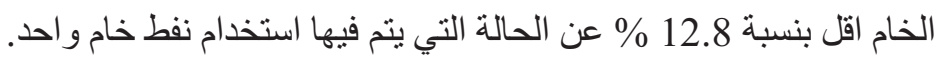

\section{$\underline{\text { Abstract }}$}

The primary objective of this study is to predict optimum refining strategy to fractionate various Iraqi crude oils into lighter fractions depending on market monthly demand along one year.

The monthly consumption of gasoline, kerosene and diesel was calculated and genetic algorithm optimization method was used to calculate optimum cut points and blending ratio of three different crude oils (light Basrah, heavy Basrah and Kirkuk).

The results prove that manipulation cut points within a year for a blend of three crude oils will decrease $12.8 \%$ of distilled crude oil to produce the required amount of light cuts produced by refining single crude oil.

Keywords crude oil, true boiling point, cut point, genetic algorithm, optimization.

\section{Introduction}

Optimization is very important to select the optimum crude oils feedstock, blending ratio, cut point temperatures and operating conditions. Several researchers applied stochastic optimization methods in optimization operating conditions of crude oil refinery [1-8]. Lekan et al. [1] 
proposed a model to optimize the atmospheric distillation column of a crude oil. The proposed optimization model is applicable for the change in feed stock, market situations and products prices. Sayed et al. [2] simulate a crude oil distillation unit using nonlinear steady-state model embedded in the Aspen Hysys V 7.3. The model optimized using sequential quadratic programming (SQP) algorithm. Processing different crude oils blended in different proportions were optimized to maximize total profit. By optimizing the weekly scheduling at the operational level they obtained 0.89 million American dollars weekly average profit. Yiqing et al. [3] applied Aspen Plus to simulate and optimize the crude oil distillation unit. Particle swarm optimization (PSO) algorithm was used to obtain optimum operating conditions of the existing distillation column with considering energy recovery and product profit. The optimized operating conditions include product yields, stripping steam flowrate and pump-around heat duties. Ahmed and Ala'a [4] used Aspen Hysys V. 7.1 to simulate and optimize the naphtha stabilizer in Al-Basrah Refinery. They proved that, it's possible to maximize the C5+ in reformate from $97 \%$ in real unit to $99.6 \%$ by selection the optimum design variables and operating conditions. Ali et al. [5] applied hybrid optimization algorithm which combines the Hysys simulation and genetic algorithm (GA) optimization method written by Matlab to optimize design variables of the atmospheric distillation column. Shankar et al. [6] simulate real crude plant using Aspen Hysys. Experimental and simulated true boiling point for kerosene, light gas oil and atmospheric residue were taken into account in analysis of the crude distillation unit.

Most of previous studies concern with applying simulation results to optimize operating conditions of atmospheric distillation column[1-6], little other researchers used optimization to select optimum blending ratio and cut points temperatures [7,8]. Ganji et al.[7] developed a mathematical model able to predict the optimum crude oils blending ratios feed to refinery. Their model utilizes linear and non-linear programming equations to characterize the crude oils, optimum blending ratio and calculate the properties of blended crude oil. Their results show that different types of crudes with different API gravity (15 to 50) could be feed to refineries with suitable blending ratios. Faizan and Yusoff [8] applied Taguchi method to optimize the light crudes fractionation by manipulating cut-point of naphtha, kerosene, light and heavy diesel, atmospheric gasoil and the residue. Optimization increases the diesel production whilst decreasing energy consumption. Their results showed that 20 to $41 \%$ benefits can be achieved as compared to straight run temperatures. 
In Iraq varying the demand for light cuts within a year make scheduling production of light cuts is very important. Kerosene is consumed in winter for home heating while the gas oil consumption is increased in summer due to increasing the consumption in local electrical generators. This study concerns with the planning and scheduling of the crude oil feed involving the blending of different crudes to reduce the supply-demand gap of the refinery products.

\section{Case Study}

Figures (1, 2 and 3) represent gasoline, kerosene and diesel monthly consumption in Iraq within one year in 2016 [9]. It can be shown from these figures the periodic demand for light cuts within year. The demand for kerosene is high in the winter while the demand for gasoline and gasoil reach maximum in summer. Refining different crude oils produce different amounts of light cuts. Three different crude oils which are light Basrah (API=29.7), heavy Basrah $(\mathrm{API}=23.7)$ and Kirkuk (API=34.2) was studied to select optimum refinery strategy.

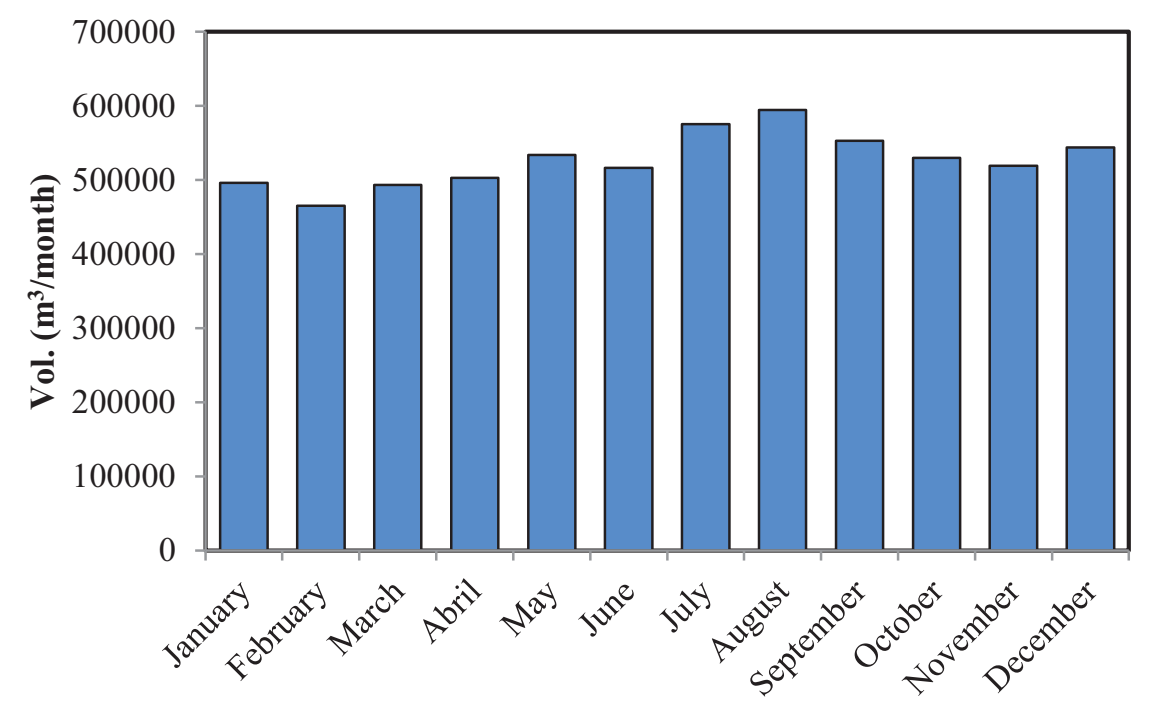

Fig. (1) Monthly Gasoline consumption in 2016. 


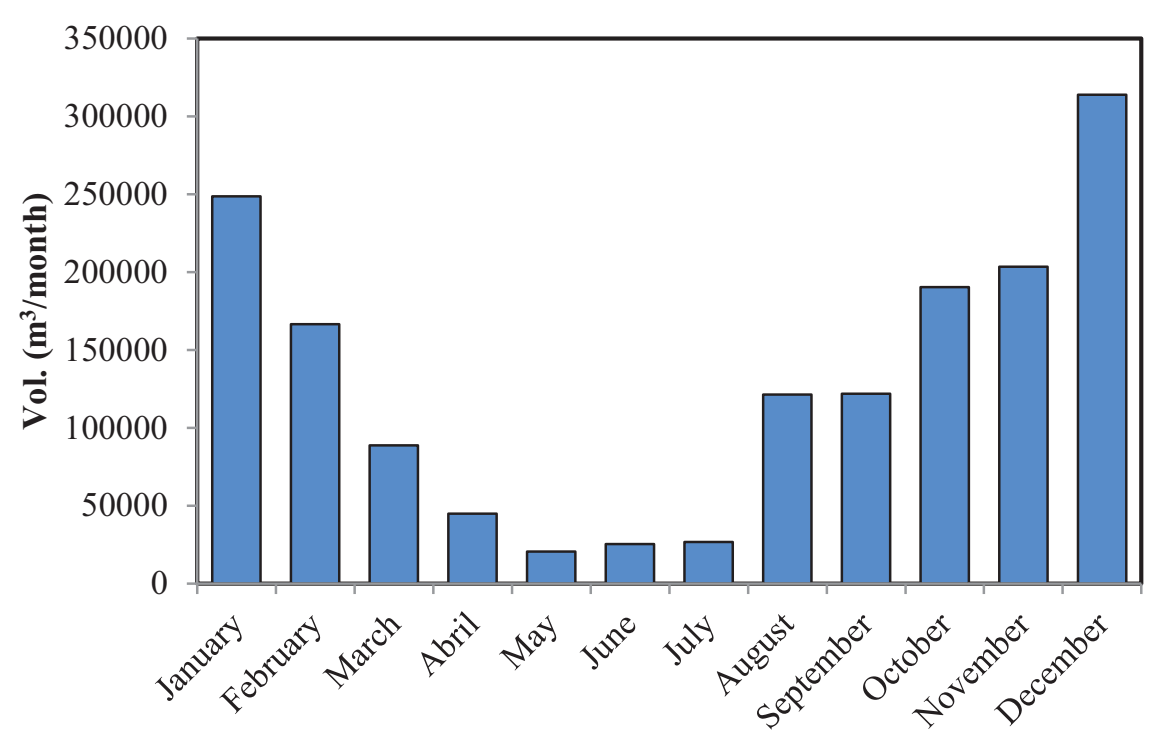

Fig. (2) Monthly Kerosene consumption in 2016.

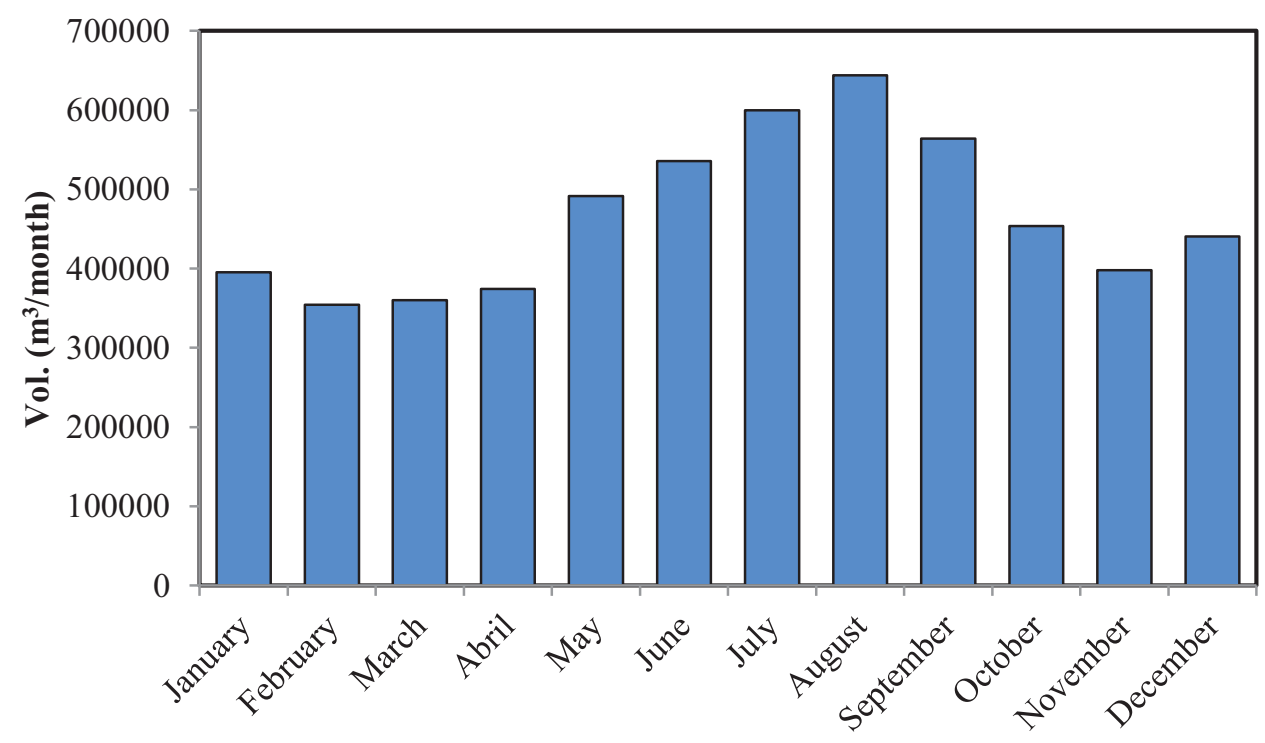

Fig. (3) Monthly Gas oil consumption in 2016. 


\section{Results and discussion}

\subsection{True boiling point curves}

For any crude oil analysis the True Boiling Point TBP curve is essential for prediction quantities of crude oil fractions. The TBP curve is a plot of the mixture boiling point as a function of cumulative weight fraction or volume fraction distilled. Figure (4) show the TBP assays of main three Iraqi crude oils used in this study. The value of TBP-volumetric yield curve of these three crude oils was taken from the website of the British petroleum (BP) company [10].

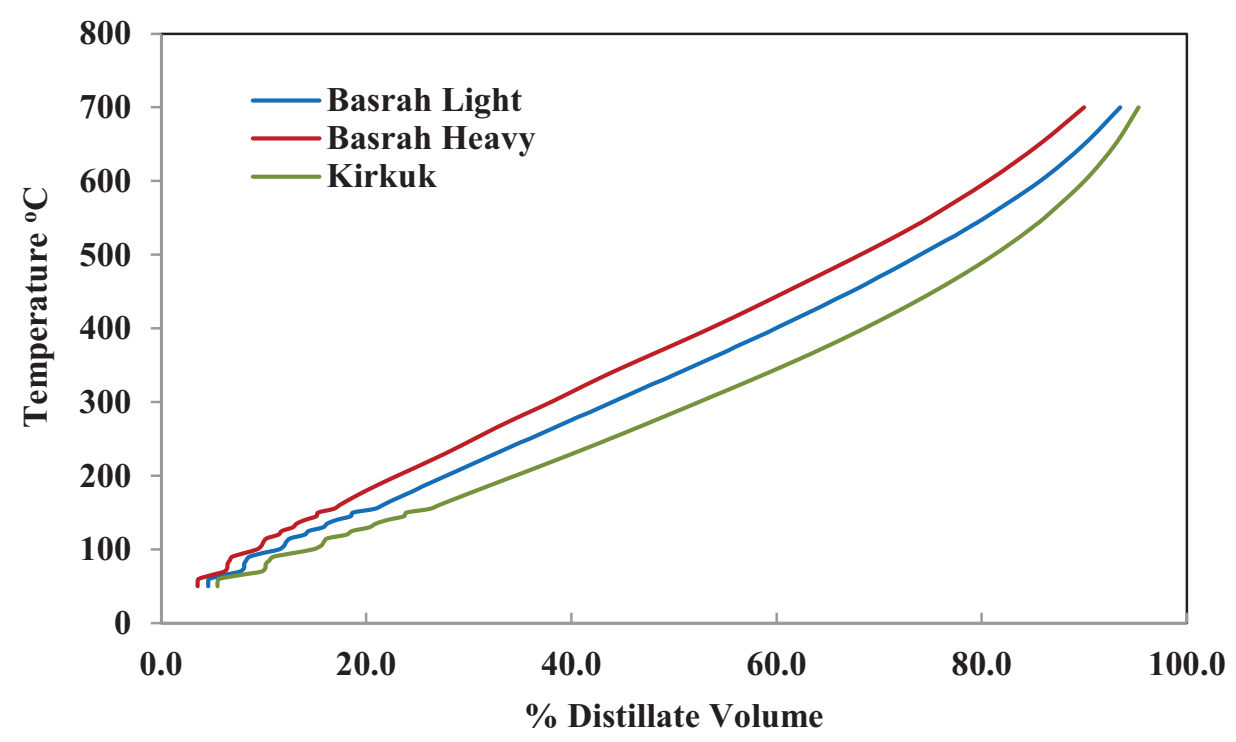

Fig. (4) TBP assays of Iraqi crude oils

Table (1) includes typical crude oil cut points range of crude oil fractions [3]. The boiling point range for a side-draw of atmospheric and vacuum distillation column is usually defined by ASTM 95\% point of a side-draw. It was assumed that the cut point selection could be manipulated within a narrow range to reach the quantity and specification requirements of products. Figure (5) show the volume fractions of light cuts at typical cut points. It was shown that, Lighter crude oils produce a excessive amounts of the lighter components. 


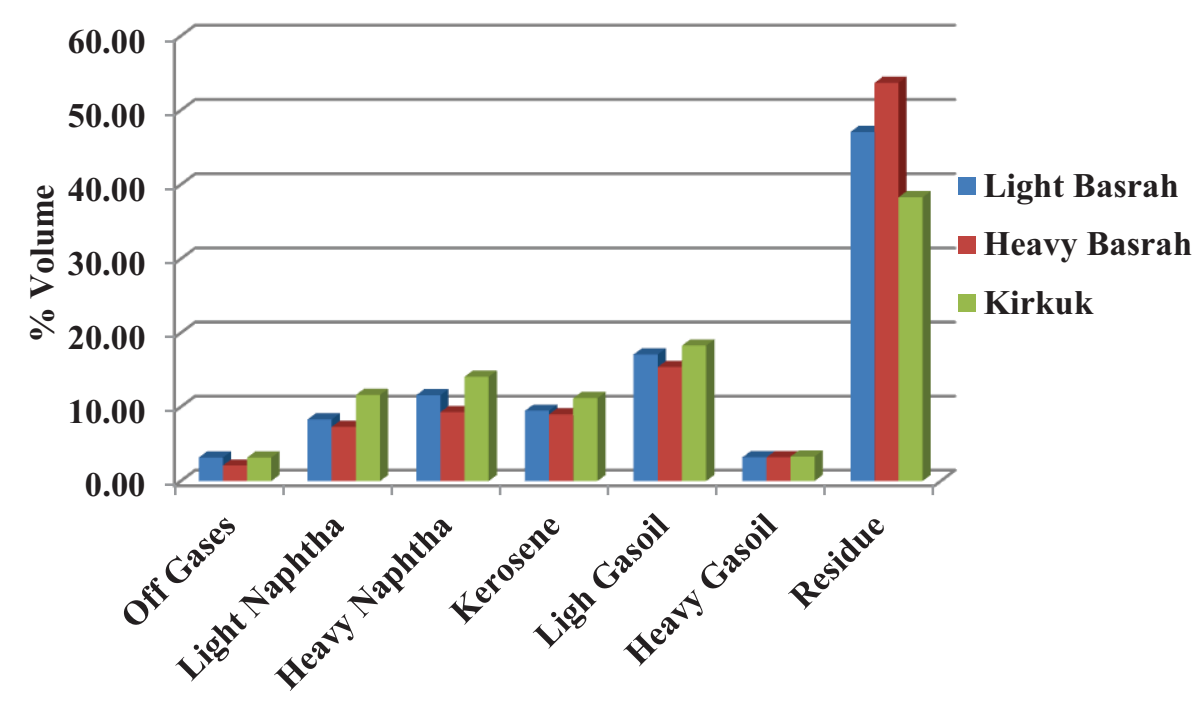

Fig. (5) volume fractions of light cuts at typical cut points.

\subsection{Optimization}

\subsubsection{Optimization}

Genetic Algorithms (GA) is a powerful optimization method based on the concepts of natural selection and natural evaluation [11]. Genetic Algorithm optimization method coded by Matlab 2014a software was used to calculate optimum refining strategy required to predict the best yield of petroleum fraction. Table (2) contains the parameters of genetic algorithm.

\subsubsection{Optimization objective function}

The volume fraction of each crude oil fraction was calculatd using the equation given below.

$\mathrm{V}_{\mathrm{i}}=\mathrm{V}_{\mathrm{i}, \mathrm{EBp}}-\mathrm{V}_{\mathrm{i}, \mathrm{IBp}}$

The total flow rate of each fraction is equal to sum of the flow rates of a fraction in crude oils blends.

$F_{i}=F_{t} \sum_{j=1}^{n c} x_{j} V_{i}$

The objective function of optimization is to produce the required quantities of petroleum fractions using minimum crude oils flow rates.

$\mathrm{F}_{\mathrm{obj}}=\min \left(\mathrm{F}_{\mathrm{t}}\right)$ 


\subsubsection{Optimization Results}

Eleven variables were taken into consideration in optimization (one for flow rate, three for blending ratio and seven for cut point temperature). The yield of petroleum fractions was calculated by selecting the optimum monthly flow rate, blending ratio and cut point temperatures of gases, light and heavy naphtha, gasoline, kerosene, diesel, and residue. The target of optimization is to produce the light cuts using minimum feedstock of three blending crude oils. Three different cases was studied (I) single crude oil of light Basrah, (II) using a blend of light and heavy Basrah crude oil, (II) using a blend of light and heavy Basrah and Kirkuk crude oils.

Figure (6) show the optimization results for the values of crude oils that produce the required amounts of light cuts. Table (3) present a summary of optimization results for using a blend of light Basrah, Heavy Basrah and Kirkuk crude oils (Case III). By comparing the results of case I and II it can be shown that in case II, $2.88 \%$ increase in the amounts of blend required for satisfying the required amounts of light cuts. While using a blend of three crude oils such as in case III required $12.8 \%$ less crude oil comparing with case (I). This is due to that different crude oils contain different amount of light cuts (gasoline, kerosene and gas oil). Therefore, blending of light and heavy crude oils is very important to achieve the desired quantities of light cuts.

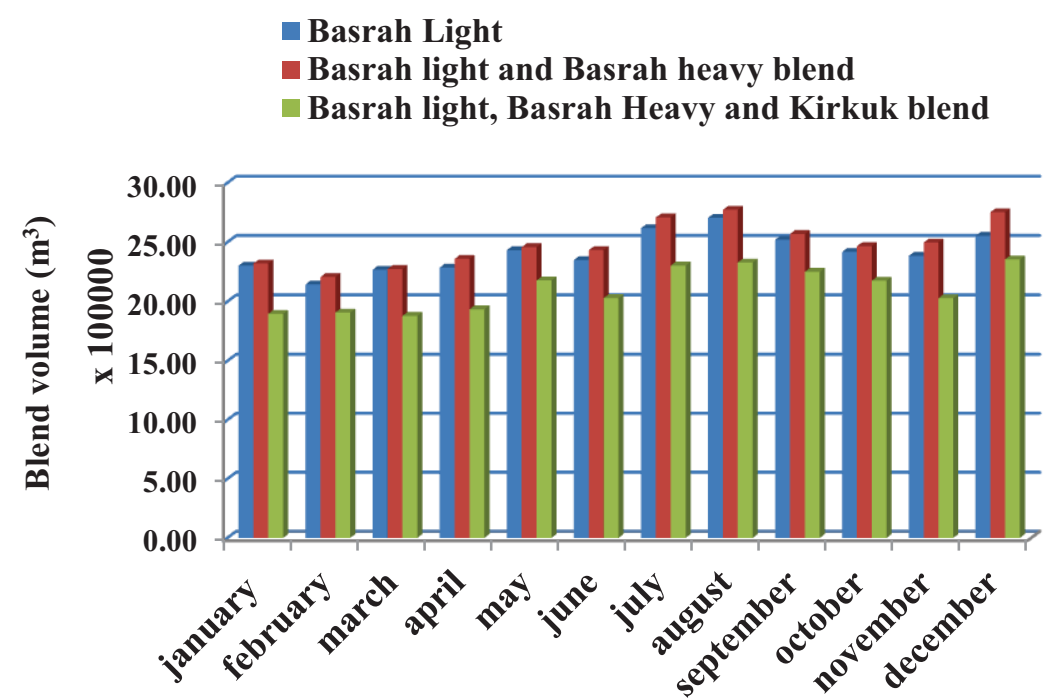

Fig. (6) Optimization results for the values of crude oils that produce the required amounts of light cuts. 


\section{Conclusion}

The monthly consumption of gasoline, kerosene and diesel was calculated and genetic algorithm optimization method was used to calculate optimum cut points and blending ratio of three different crude oils (light Basrah, heavy Basrah and Kirkuk).

The results prove that manipulation cut points within a year for a blend of three crude oils will require $12.8 \%$ less crude oil than using single crude oil to produce the required amount of light cuts.

\section{Nomenclature}

$\mathrm{F}_{\mathrm{t}}$ : total flowrate of blended crude oil.

$F_{i}$ : flowrate of $i$ crude oil.

$\mathrm{x}_{\mathrm{j}}$ : blending ratio $(\% \mathrm{Vol}$.)

$\mathrm{V}$ : Volume (m3)

API: American Petroleum Institute

TBP: True Boiling Point

\section{Subscript \\ $i$ the number of side draw \\ $j$ the number of blended crude oil}

Table (1) Typical crude oil cut points range

\begin{tabular}{|l|l|l|}
\hline Cut & TBP IBP $\left({ }^{\mathbf{0}} \mathbf{C}\right)$ & TBP EP $\left({ }^{\circ} \mathbf{C}\right)$ \\
\hline Off Gas & - & $27-32$ \\
\hline Light Naphtha & $27-32$ & $82-104$ \\
\hline Heavy Naphtha & $82-104$ & $165-193$ \\
\hline Kerosene & $165-193$ & $215-271$ \\
\hline Atmospheric Gas Oil & $215-271$ & 343 \\
\hline Light vacuum gas oil & 343 & 427 \\
\hline Heavy vacuum gas oil & 427 & $510-593$ \\
\hline Vacuum reduced crude & $510-593$ & - \\
\hline
\end{tabular}


Table (2) Genetic algorithm parameters

\begin{tabular}{|l|l|}
\hline Population size & 1000 \\
\hline Maximum generation & 100 \\
\hline Crossover probability & 0.8 \\
\hline Mutation probability & 0.05 \\
\hline Neighborhood size & 0.05 \\
\hline
\end{tabular}

Table (3) Summary of optimization results for using a blend of light Basrah, Heavy Basrah and Kirkuk crude oils (Case III).

\begin{tabular}{|c|c|c|c|c|c|c|c|c|c|c|c|c|}
\hline Three Crude oils & \begin{tabular}{|c|} 
Janu \\
ary
\end{tabular} & $\begin{array}{l}\text { Febr } \\
\text { uary }\end{array}$ & $\begin{array}{c}\text { Marc } \\
\text { h }\end{array}$ & April & May & June & July & $\begin{array}{c}\text { augus } \\
t\end{array}$ & $\begin{array}{l}\text { Septe } \\
\text { mber }\end{array}$ & $\begin{array}{c}\text { Octo } \\
\text { ber }\end{array}$ & $\begin{array}{l}\text { Nove } \\
\text { mber }\end{array}$ & \begin{tabular}{l|} 
Dece \\
mber
\end{tabular} \\
\hline $\begin{array}{c}\text { LPG cut point } \\
\text { temperature ( } C \text { ) }\end{array}$ & 28.57 & 29.77 & 30.77 & 29.02 & 30.49 & 28.59 & 31.66 & 27.62 & 31.72 & 30.33 & 28.07 & 29.16 \\
\hline $\begin{array}{c}\text { Light Naphtha cut point } \\
\text { temperature ( } \mathrm{C} \text { ) }\end{array}$ & 85.52 & $\begin{array}{c}100.7 \\
3\end{array}$ & 85.43 & 84.60 & 90.94 & 96.21 & $\begin{array}{c}100.7 \\
4\end{array}$ & $\begin{array}{c}100.3 \\
7\end{array}$ & $\begin{array}{c}101.6 \\
5\end{array}$ & 89.44 & $\begin{array}{c}102.9 \\
0\end{array}$ & 89.57 \\
\hline Heavy NaI & 192.9 & 192.9 & 193.0 & 192.8 & 192.9 & 192.9 & 192.9 & 192.9 & 192.7 & 192.9 & 192.8 & 190.7 \\
\hline temper & 3 & 5 & 0 & 9 & 7 & 8 & 1 & 7 & 7 & 3 & 7 & 8 \\
\hline Kero & 267.8 & 263.1 & 239.0 & 221.3 & 239.1 & 241.8 & 249.1 & 250.3 & 246.9 & 247.0 & 258.9 & 270.2 \\
\hline tempe & 9 & 4 & 4 & 4 & 7 & 9 & 1 & 0 & 8 & 5 & 2 & 1 \\
\hline LGO cut point & 343.0 & 343.0 & 343.0 & 343.0 & 343.0 & 343.0 & 343.0 & 343.0 & 343.0 & 343.0 & 343.0 & 343.0 \\
\hline temp & 0 & 0 & 0 & 0 & 0 & 0 & 0 & 0 & 0 & 0 & 0 & 0 \\
\hline HGO cut point & 427.0 & 427.0 & 427.0 & 427.0 & 427.0 & 427.0 & 427.0 & 427.0 & 427.0 & 427.0 & 427.0 & 427.0 \\
\hline temperature ( C ) & 0 & 0 & 0 & 0 & 0 & 0 & 0 & 0 & 0 & 0 & 0 & 0 \\
\hline Resiu & 582.0 & 512.3 & 572.6 & 589.1 & 540.6 & 578.5 & 519.4 & 540.6 & 549.8 & 513.8 & 576.8 & 585.8 \\
\hline temperature ( C ) & 4 & 0 & 4 & 2 & 4 & 9 & 0 & 6 & 8 & 4 & 2 & 9 \\
\hline Blend volun & 8970 & 907 & 8803 & 935 & 1789 & 20301 & 23038 & 23298 & 251 & 2176 & 20292 & 23563 \\
\hline (m3/month) & 97 & 88 & 25 & 48 & 43 & 45 & 82 & 10 & 93 & 59 & 08 & 05 \\
\hline $\begin{array}{c}\text { Crude oil } 1 \text { fraction } \\
\text { (vol/vol) }\end{array}$ & 0.10 & 0.03 & 0.16 & 0.19 & 0.10 & 0.17 & 0.07 & 0.10 & 0.14 & 0.29 & 0.04 & 0.35 \\
\hline $\begin{array}{c}\text { Crude oil } 2 \text { fraction } \\
\text { (vol/vol) }\end{array}$ & 0.11 & 0.34 & 0.06 & 0.07 & 0.28 & 0.15 & 0.24 & 0.17 & 0.25 & 0.19 & 0.20 & 0.23 \\
\hline Crude oil 3 fraction & \begin{tabular}{|l|}
0.81 \\
\end{tabular} & 0.63 & 0.78 & \begin{tabular}{|l|}
0.74 \\
\end{tabular} & \begin{tabular}{|l|}
0.62 \\
\end{tabular} & 0.69 & 0.68 & 0.73 & 0.61 & 0.52 & 0.76 & \begin{tabular}{|l|}
0.42 \\
\end{tabular} \\
\hline
\end{tabular}




\begin{tabular}{|l|l|l|l|l|l|l|l|l|l|l|l|l|}
\hline (vol/vol) & & & & & & & & & & & & \\
\hline
\end{tabular}

\section{$\underline{\text { References }}$}

1. Lekan T. P., Jamiu A. A., and Solomon O. A., "Investigations into Optimization Models of Crude Oil Distillation Column in the Context of Feed Stock and Market Value", Advances in Chemical Engineering and Science, 2, pp 474-480, (2012).

2. Syed F. A., Nooryusmiza Y., Saibal G., Mardhati Z. A., and Khairiyah S., "Profit Maximization of a Crude Distillation Unit", Proceedings of the 6th International Conference on Process Systems Engineering (PSE ASIA), Kuala Lumpur. (25 - 27 June 2013).

3. Yiqing L., He W., and Xigang Y. "Simultaneous optimization for heat-integrated crude oil distillation system", 6th International Conference on Process Systems Engineering (PSE ASIA), Kuala Lumpur 25 - 27,(June 2013).

4. Ahmed R. H. and Ala'a A. J. "Enhance C5 ${ }^{+}$Recovery Predicting and Maximizing the Reformate Production in Naphtha Stabilizer Using HYSYS" Journal of Chemical, Biological and Physical Sciences, Vol. 4, No. 3; pp 1851-1865, (2014).

5. Ali K. K., Ajeet K. R., and Abdulwahid A. A.," Optimizatin and Performance Evaluation of An Existing Crude Oil Distillation System”, IJARET, V 5, Issue 4, pp. 94-102, April (2014).

6. Shankar N., Aneesh V. and Sivasubramanian V. "Aspen Hysys based Simulation and Analysis of Crude Distillation Unit", International Journal of Current Engineering and Technology, Vol.5, No.4 (Aug 2015).

7. Ganji H., Zahedi S., Ahmadi Marvast M., Kananpanah S., Sadi, M. Shokri S.," Determination of Suitable Feedstock for Refineries Utilizing LP and NLP Models International Journal of Chemical Engineering and Applications", Vol. 1, No. 3, October 2010 .

8. Faizan S. A.,Yusoff N. "Determination of Optimal Cut Point Temperatures at Crude Distillation Unit using the Taguchi Method" International Journal of Engineering \& Technology IJET-IJENS Vol:12 No:06,(December 2012).

9. Oil Products Distribution Company $\backslash$ Ministry of Oil $\backslash$ Iraq.

10. British Petroleum Bp company website (www.bp.com/content/dam/bp-crudes/ en/Assays/)

11. Namita K., Anju R., Akshatha.P.S,'Genetic Algorithm: A Search of Complex Spaces" International Journal of Computer Applications (0975 - 8887), Volume 25- No.7, July 2011. 